П.М. Перехрестенко, В.М. Самусь, О.М. Аладьєва

Ду «нститут гематології та трансфузіології НАМН України», Київ

\title{
Аналіз діяльності закладів служби крові України у 2017 р.
}

Аналіз діяльності закладів служби крові - значне теоретичне та практичне підґрунтя для планування роботи самої служби і для оцінки та планування ресурсних можливостей напрямів медицини, пов'язаних із результатами роботи служби як в регіонах, так і в цілому по Україні. Аналітичні матеріали призначені для керівників управлінь охорони здоров'я, головних обласних та міських трансфузіологів, гематологів, хірургів, акушерів-гінекологів, анестезіологів-реаніматологів, фахівців інших спеціальностей.

ключові слова: донори, донації, кров, плазма, еритроцитна маса, тромбоцити, продукція на одного працюючого, забезпеченість на 1000 населення.

\section{Вступ}

Служба крові - один із важливих пріоритетних розділів медицини, який має стратегічне значення, особливо нині, коли відбуваються військові дії на Сході України. Вона повинна забезпечити надання трансфузіологічної допомоги хворим та постраждалим, від чого залежить не лише здоров'я, а нерідко і життя пацієнтів (МO3 України, 1995).

Мета роботи - проаналізувати діяльність центрів та станцій переливання крові, відділень трансфузіології лікувальних закладів (ВТЛЗ) областей, міста Києва та закладів, безпосередньо підпорядкованих Міністерству охорони здоров'я (МО3) України, Національній академії медичних наук (НАMН) України, Міністерству оборони України.

\section{Об'єкт і методи дослідження}

Аналіз проведено на підставі звітів «Галузева статистична звітність - форма № 39-здоров», «Звіт центру служби крові (станції переливання крові), ВТЛЗ, установи, лікарні, яка проводить заготівлю крові, областей, міста Києва та відомчих закладів. Проведено статистичну обробку одержаних матеріалів.

\section{Результати та їх обговорення}

Станом на 01.01.2018 р. в Україні функціонували 43 центри (станції) переливання крові, з них - 24 обласних і 18 міських центрів, 1 відомчий - Міністерства оборони України. Крім того, було 309 ВТЛЗ, з них 6 підпорядковані МОЗ України і 6 - НАМН України. Заготівлю крові проводили 76 лікарень (Перехрестенко П.М. та співавт., 2018).

У зв'язку із продовженням оптимізації мережі та передачею в інше підпорядкування закладів служби крові Укрзалізниці кількість центрів (станцій) переливання крові у 2017 р. зменшилася на 1, ВТЛ3 - на 6, лікарень, що заготовляють кров, - на 1.

У закладах служби крові нараховувалося 7230,5 штатних посад (у2016 р. - 7425,5), з них: лікарів - 1334,25 (у 2016 р. - 1357,5), в тому числі зайнято біологами - 237,5 посади; середнього медичного персоналу - 2483,25 (у 2016 р. - 2510,5). Укомплектованість штатних посад становила 88,7\% (у 2016 р. - 90,2\%), із них лікарями - 64,5\% (у2016 р. -68,0\%), середнім персоналом - 81,5\% (у2016 р. - 82,5\%).

На заготівлю крові та ї̈ компонентів у 2017 р. спрямовано 55,4\% штатних одиниць (у 2016 р. - 53,0\%). На виготовлення препаратів плазми крові - 3,9\% (у 2016 р. - 8,0\%) загальної кількості посад. Це зумовлено припиненням виробництва препаратів центрами та станціями переливання крові.

\section{Оснащеність закладів служби крові України}

Усі заклади служби крові мають апарати для проведення автоматичного плазмаферезу та цитаферезу, лабораторіями полімеразної ланцюгової реакції укомплектовані 5 центрів служби крові (Запорізький та Київський обласні, Сумський та 2 ВТЛЗ МОЗ України).

\section{Аналіз показників виготовлення продукції на одного}

працюючого в закладах служби кров

В середньому в Україні на одного працюючого в службі крові в 2017 р. заготовлено 41,1 л крові та 24,4 л плазми крові.
По заготівлі крові на одного працюючого найкращі показники у Дніпропетровській (71,6 л), Миколаївській $(68,4$ л), Хмельницькій (54,0 л), областях, нижче середніх по Україні - в Тернопільській (18,0 л), Кіровоградській (24,7 л), Херсонській (25,1 л) областях.

Результати аналізу заготівлі плазми крові на одного працюючого свідчать, що в Сумській області цей показник вище середнього по Україні майже в 11 разів (260,0 л). Високі показники також у Миколаївській (42,1 л), Дніпропетровській (30,0 л), Хмельницькій (24,6 л) областях. Значно нижчі показники від середніх по Україні в Кіровоградській (10,7 л), Рівненській (12,3 л), Черкаській (12,3 л), Херсонській (13,3 л) областях (табл. 1).

Загальна кількість донорів порівняно з 2016 р. зменшилася на 18655 (4,8\%) осіб. Зменшення відбулося практично по всіх регіонах, крім Волинської, Донецької, Одеської, Полтавської, Рівненської, Херсонської, Харківської, Черкаської областей та міста Києва (Перехрестенко П.М. та співавт., 2017).

Донори крові від загальної кількості становили 90,4\%, донори плазми крові $-7,8 \%$, донори клітин крові - 1,8\% (рис. 1). $\frac{\text { Таблиця 1. Ефективність діяльності закладів служби крові регіонів України }}{\text { Показники діяльності служби крові регіону }}$

\begin{tabular}{|c|c|c|c|c|c|c|}
\hline \multirow[b]{3}{*}{ Регіон (область) } & \multicolumn{6}{|c|}{ ПоКаззники дІяльностІ служои кровІ регіону } \\
\hline & \multicolumn{3}{|c|}{ на 1 зайняту посаду } & \multicolumn{3}{|c|}{ на 1 апарат аферезу } \\
\hline & 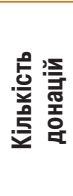 & 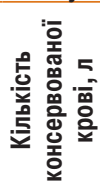 & 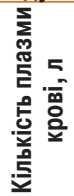 & 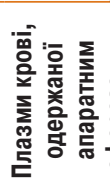 & 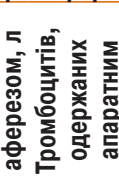 & 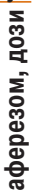 \\
\hline нницька & 93 & 46,4 & 21,9 & 49 & 363 & \\
\hline олинська & 88 & 35,4 & 17,2 & 178,6 & 630 & \\
\hline ніпропетровська & 118 & 71,6 & 30,0 & 111,7 & 423 & \\
\hline онецька & 69 & 33,9 & 16,9 & 188,4 & 189 & \\
\hline 〈итомирська & 71 & 34,3 & 17,0 & 53,6 & 589 & \\
\hline акарпатська & 72 & 33,5 & 14,6 & 22,6 & 318 & \\
\hline апорізька & 73 & 34,5 & 17,0 & 128,2 & 295 & \\
\hline зано-Франківська & 74 & 31,0 & 14,3 & 68,0 & 529 & \\
\hline иївська & 81 & 42,7 & 20,8 & 1,1 & 90 & \\
\hline іровоградська & 54 & 24,7 & 10,7 & 19,2 & 195 & \\
\hline ууганська & 81 & 42,4 & 20,1 & 190,6 & 112 & \\
\hline ьвівська & 70 & 32,4 & 14,5 & 33,4 & 568 & \\
\hline Ииколаївська & 149 & 68,4 & 42,1 & 205,7 & 656 & \\
\hline деська & 88 & 40,6 & 21,5 & 87,2 & 186 & \\
\hline олтавська & 82 & 37,4 & 19,3 & 10,8 & 687 & \\
\hline івненська & 60 & 28,5 & 12,3 & 5,6 & 354 & \\
\hline умська & 410 & 30,5 & 260,0 & 1003,0 & 197 & \\
\hline ернопільська & 50 & 18,0 & 13,4 & 381,0 & 22 & \\
\hline арківська & 87 & 41,5 & 21,7 & 116,5 & 244 & \\
\hline ерсонська & 54 & 25,1 & 13,3 & 114,0 & 350 & \\
\hline мельницька & 120 & 54,0 & 24,6 & 69,7 & 327 & \\
\hline еркаська & 60 & 28,1 & 12,3 & 70,5 & 353 & \\
\hline ернівецька & 70 & 33,7 & 16,0 & 53,1 & 197 & \\
\hline ернігівська & 96 & 42,2 & 22,7 & 259,0 & 150 & \\
\hline . Київ & 96 & 44,8 & 23,5 & 111,4 & 808 & \\
\hline країна & 89 & 41,1 & 24,4 & 337,7 & 326 & \\
\hline
\end{tabular}




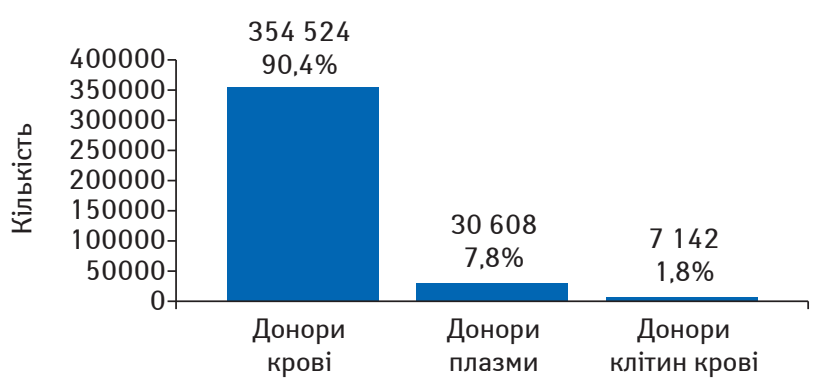

Рис. 1. Донори крові, плазми крові, клітин крові

Середня частка донорів від загальної кількості населення регіонів у 2017 р. становила 0,93\% (у 2016 р. - 0,97\%). Вище середнього по Україні цей показник був у Хмельницькій (1,89\%), Запорізькій $(1,44 \%)$, Волинській $(1,86 \%)$, Дніпропетровській $(1,23 \%)$, Миколаївській $(1,20 \%)$ областях. Найнижчий показник - у Донецькій $(0,34 \%)$, Луганській $(0,48 \%)$, Житомирській $(0,71 \%)$, Херсонській (0,73\%), Харківській $(0,73 \%)$ областях.

Для порівняння у 2013 р. в країнах Європейського Союзу (ЄС) питома вага донорів у середньому становила 2,4\% кількості населення. Рівнем самодостатності у забезпеченні продуктами крові вважається $\geqslant 3,0 \%$ донорів. Показник 1,0\% донорів від населення оцінюється як такий, що створює проблеми із забезпеченням країни кров'ю, ї̈ компонентами та препаратами (Чугрієв А.М., 2017).

У 2017 р. кількість донорів плазми крові в Україні зменшилася на 7316 (20\%) осіб. Імунні донори були лише у Сумській області 38 донорів, ізоімунні - у Сумській (70), Донецькій (29), Хмельницькій (6), Вінницькій (5), Запорізькій (4), Черкаській (3), Дніпропетровській (1), Львівській (1) областях.

Кількість донацій крові, плазми крові та клітин крові становила 581080 (що на 20027 (або на 3,5\%) менше, ніж у 2016 р.), із них кроводач - 486706 , плазмодач - 84373 , донацій клітин крові 10001 (рис. 2)

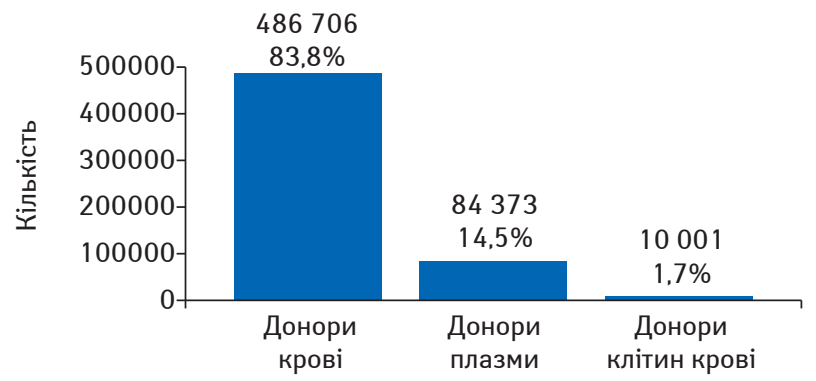

Рис. 2. Донації крові, плазми крові, клітин крові

Донації на 1000 осіб населення України у 2017 р. становили 13,05 (у 2016 р. - 14,2), із них кроводач - 10,89 (у 2016 р. - 11,04), плазмодач $-1,98$ (у 2016 р. - 2,21) та донацій клітин крові $-0,18$ (y 2016 p. $-0,26$ ).

Кількість донацій крові у країнах $€ С$ в 2013 р. становила 36 на 1000 населення (Чугрієв А.М., 2017). На європейському рівні за кількістю донацій на 1000 населення показник лише в Сумській області - 49,29 (за рахунокплазмаферезу - 41,76). У межах $\geqslant 20$ донацій на 1000 населення ще в 5 областях (Хмельницька $-25,33$, Волинська $-25,29$, Миколаївська $-22,52$, Запорізька $-19,81$, Дніпропетровська - 18,12). У 6 регіонах цей показник <10 (Луганська - 4,8, Донецька - 6,79, Житомирська - 8,49, Київська - 9,31, Львівська - 9,36 області та місто Київ - 9,78) (табл. 2).

Кількість відведених від донацій донорів порівняно з 2016 p. зменшилася на 4197 осіб і становить 29292 (7,5\%) особи від усіх донорів.

Середня доза кроводачі у 2017 р. по країні була 422,0 мл, у 2016 р. - 418,7 мл. Менше середньої дози - уВолинській (388,1 мл), Івано-Франківській (399,0 мл), Чернігівській (413,0 мл) областях.

У 2017 р. заготовлено 263 672,3 л консервованої донорської крові (у 2016 р. - 257238,6 л). Із загальної її кількості на виготовлення компонентів та стандартних сироваток використано 96,6\% (254586,1 л)

Особливо зазначимо, що у 2017 р. всі регіони, крім Чернігівської та Донецької областей, відмовилися від трансфузій цільної крові. у Чернігівській області перелили 69,5 л, у Донецькій - 2,6 л цільної крові.

Брак консервованої донорської крові у 2017 р. становив 1,07\% це 2834,7 л, що на 675,7 л менше, ніж у 2016 р. Суттєвий брак крові відзначали у зв'язку з виявленням антитіл до вірусу гепатиту C 297,9 л (0,11\%), поверхневого антигену вірусу гепатиту В - 227,0 л $(0,09 \%)$, блідої спірохети - 178,9 л (0,07\%). Брак крові у зв'язку з виявленням антитіл до ВІЛ 1/2 становив 100,8 л (0,04\%) (у 2016 р. 191,2 л). Браку зв'язкуз підвищенням показників аланінамінотрансферази (АлАТ) - 593,7 л (0,23\%) (МО3 України, 2005a).

\section{Компоненти крові}

У 2017 р. заготовлено 121 926,3 л еритроцитної маси. Лікувально-профілактичними закладами для трансфузій використано 85703,4 л (70,3\%). Цей показник вищий на 6,5\% відпоказника 2016 р. 3 різнихпричин забраковано $5,6 \%$ (6800,9 л). Узв'язку із закінченням терміну зберігання списано 11,6\% еритроцитної маси, що становило 14 102,6 л. У 2016 р. утилізовано (списано + брак) 21 147,0 л еритроцитної маси (МОЗ України, 2013а).

у 2017 р. в Україні заготовлено 156 819,2 л плазми крові (що на 5700,1 л менше порівняно з 2016 р.). У середньому вихід плазми крові 1 л консервованої крові становив 47,6\% (467,4 мл) (у2016 р. 47,0\% - 466,5 мл).

Мануальним та автоматичним плазмаферезом одержано 47 717,3 л плазми крові, або 30,4\% усієї заготовленої (у 2016 р. ця частка становила $32,6 \%)$. Методом автоматичного плазмаферезу одержано 26,8\% (42 080,0 л) плазми крові від об'єму всієї заготовленої, а мануальним плазмаферезом - 3,6\% (5637,3 л).

Середні дози плазми крові припроведенні автоматичного плазмаферезу становили 668,7 мл (у 2016 р. - 646,6 мл). Вище середнього показники в Хмельницькій (833,0 мл), Київській (733,0 мл), Черкаській (758,0 мл), Сумській (710,0 мл), Чернігівській (708,8 мл) областях. Значно нижчі середнього показники в Кіровоградській (337,0 мл), Полтавській (400,0 мл), Волинській (445,0 мл), Одеській (470,0 мл), Херсонській (472,0 мл) областях. Середні дози плазми крові при проведенні однократного мануального плазмаферезу 276,4 мл, двократного - 594,7 мл.

Бракплазми крові від всієї заготовленої у 2017 р. становив 4,8\% (у 2016 р. - 5,0\%), тобто 7595,2 л виявилися непридатними для використання. Більше всього забраковано плазми крові з причини виявлення антитіл до вірусу гепатиту C - 14,9\% (1132,3 л), поверх-

Таблиця 2. Основні показники забезпеченості на 1000 населення регіонів України

\begin{tabular}{|c|c|c|c|c|c|}
\hline Регіон (область) & $\begin{array}{l}\text { 응 } \\
\text { 옹 } \\
\text { 몬 }\end{array}$ & 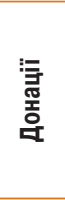 & 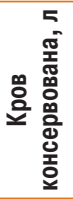 & 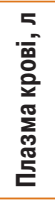 & 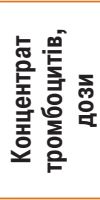 \\
\hline Вінницька & 8,9 & 10,8 & 5,4 & 2,6 & 0,4 \\
\hline Волинська & 18,6 & 25,3 & 10,1 & 4,9 & 1,3 \\
\hline Дніпропетровська & 12,3 & 18,1 & 11,0 & 4,6 & 0,9 \\
\hline Донецька & 3,4 & 6,8 & 3,4 & 1,7 & 0,2 \\
\hline Житомирська & 7,1 & 8,5 & 4,1 & 2,1 & 0,5 \\
\hline Закарпатська & 6,5 & 9,9 & 4,6 & 2,0 & 0,4 \\
\hline Запорізька & 14,4 & 19,8 & 9,4 & 4,6 & 0,6 \\
\hline Івано-Франківська & 8,0 & 10,5 & 4,4 & 2,1 & 0,5 \\
\hline Київська & 7,5 & 9,3 & 4,9 & 2,4 & 0,5 \\
\hline Кіровоградська & 9,0 & 11,3 & 5,2 & 2,3 & 0,6 \\
\hline Луганська & 4,8 & 4,8 & 2,5 & 1,2 & 0,1 \\
\hline Львівська & 8,9 & 9,4 & 4,4 & 1,9 & 0,5 \\
\hline Миколаївська & 12,0 & 22,5 & 10,3 & 6,3 & 1,3 \\
\hline Одеська & 8,8 & 11,4 & 5,3 & 2,8 & 0,4 \\
\hline Полтавська & 9,9 & 14,3 & 6,5 & 3,4 & 0,8 \\
\hline Рівненська & 8,6 & 10,4 & 5,0 & 2,2 & 0,7 \\
\hline Сумська & 7,3 & 49,3 & 3,7 & 31,2 & 0,2 \\
\hline Тернопільська & 7,7 & 10,0 & 3,8 & 3,1 & 0,2 \\
\hline Харківська & 7,3 & 10,9 & 5,2 & 2,7 & 0,6 \\
\hline Херсонська & 7,3 & 10,7 & 5,0 & 2,7 & 0,9 \\
\hline Хмельницька & 18,9 & 25,3 & 11,3 & 5,2 & 0,8 \\
\hline Черкаська & 10,1 & 12,5 & 5,9 & 2,6 & 0,9 \\
\hline Чернівецька & 6,8 & 10,7 & 5,2 & 2,5 & 1,2 \\
\hline Чернігівська & 9,4 & 13,3 & 5,8 & 3,1 & 0,3 \\
\hline м. Київ & 7,9 & 9,8 & 4,6 & 2,4 & 1,2 \\
\hline Україна & 9,3 & 13,1 & 6,2 & 3,7 & 0,8 \\
\hline EC (2013 p.) & 24,0 & 36,0 & - & - & - \\
\hline
\end{tabular}


Таблиця 3. Плазма крові. Списано по закінченню терміну зберігання, л

\begin{tabular}{lccc}
\multicolumn{1}{c}{ Регіон (область) } & $\mathbf{2 0 1 5} \mathbf{p .}$ & $\mathbf{2 0 1 6} \mathbf{p .}$ & $\mathbf{2 0 1 7} \mathbf{~ p .}$ \\
\hline Вінницька & 39,8 & 192,7 & 20,0 \\
Волинська & - & - & - \\
Дніпропетровська & 62,1 & 38,2 & 39,6 \\
Донецька & - & - & - \\
Житомирська & 73,3 & 17,9 & 79,9 \\
Закарпатська & 53,3 & - & - \\
Запорізька & 8,7 & 1,3 & 26,2 \\
Івано-Франківська & - & - & 51,2 \\
Киівська & 43,0 & 15,1 & 393,4 \\
Кіровоградська & 1200,6 & 823,5 & 656,7 \\
Луганська & 515,0 & 340,0 & - \\
Львівська & 426,2 & 363,7 & 663,7 \\
Миколаївська & - & - & - \\
Одеська & 138,4 & 251,0 & 232,8 \\
Полтавська & 2,2 & 14,2 & - \\
Рівненська & - & - & - \\
Сумська & - & - & - \\
Тернопільська & - & - & - \\
Харківська & - & - & - \\
Херсонська & - & - & 2,2 \\
Хмельницька & - & - & - \\
Черкаська & 37,6 & 26,1 & 62,0 \\
Чернівецька & 42,3 & 895,5 & 697,7 \\
Чернігівська & - & - & - \\
м. Київ & 17,0 & - & - \\
Україна & $\mathbf{2 6 5 9 , 5}$ & $\mathbf{2 9 7 9 , 2}$ & $\mathbf{2 9 2 5 , 4}$ \\
\hline
\end{tabular}

невого антигену вірусу гепатиту В - 12,0\% (908,3 л), антитіл до блідої спірохети - 8,4\% (635,5 л). Брак у зв'язку з виявленням антитіл до ВІЛ $1 \frac{1}{2}$ становив 5,4\% (409,9 л). Високі показники АлАТ при заготівлі плазми крові виявлено у 19,0\% (1442,5 л), білірубіну - у 0,9\% (70,0 л) (МОЗ України, 2010).

Традиційно при аналізі роботи служби крові звертали увагу на списання еритроцитної маси по закінченню терміну зберігання. А в останні роки у зв'язку з припиненням виробництва препаратів в окремих областях списано по закінченню термінузберігання значну кількість плазми крові (табл. 3).

Карантинізацію плазми крові проводили у всіх закладах служби крові України (МОЗ України, 2005б). На карантинізацію закладено 149 164,4 л (95,1\%) (у 2016 р. -154 192,9 л (94,9\%)) плазми крові від заготовленої. У лікувально-профілактичні заклади для трансфузій видано 54,8\% (81 814,7 л) карантинізованої плазми крові (2016р. 47,2\%; 72 805,1 л). На виготовлення препаратів використано 7,1\% (17 357,8 л), а у 2016 р. - 14,4\% (36 493,9 л) карантинізованої плазми крові. Максимальна частка карантинізованої плазми крові у Сумській $(99,0 \%)$, Чернігівській (98,5\%), Хмельницькій $(97,5 \%)$, Харківській $(97,4 \%)$ областях.

Під час карантинізації забраковано 1928,0 л (1,3\%). Карантинізована плазма крові вибраковувалася при виявленні у донорів поверхневого антигену вірусу гепатиту В $(16,7 \%)$, антитіл до вірусу гепатиту C (10,3\%), антитіл до блідої спірохети (5,9\%), ВІЛ 1⁄2 (6,8\%), високих показників АлАТ (4,4\%) (МОЗ України, 2013б).

\section{Виробництво препаратів плазми крові}

Із усієї заготовленої плазми крові закладами служби крові на препарати використано 10,1\% (у 2016 р. - 46,1\%), на компоненти $46,8 \%$ (у 2016 р. - 46,1\%), на стандартні сироватки 0,3\% (у 2016 р. також 0,3\%). Падіння показників порівняно із 2016 р. пов'язане з припиненням виробництва препаратів у всіх центрах (станціях) переливання крові.

\section{Заготівля та використання концентрату тромбоцитів}

У 2017 р. заготовлено 33 557,0 доз тромбоцитів, із них: концентрату з 500 мл консервованої крові - 15 627,0 доз, аферезних тромбоцитів - 20349,0 доз. Використано для трансфузій у лікувально-профілактичних закладах 91,9\% (30 840,0 доз) заготовлених тромбоцитів.

\section{Висновки}

Служба крові України потребує корінної реорганізації. На наш погляд, слід першочергово забезпечити централізоване управління з належним фінансуванням з Державного бюджету закладів, які заготовляють кров та її компоненти.

3 метою підвищення безпеки донорської крові необхідно перейти до добровільного безоплатного донорства, розробити та затвердити реєстр донорів України.
Основні завдання служби крові України

- Розробка сучасної редакції Закону України «Про донорство крові та її компонентів»;

- створення клінічної настанови про застосування донорської крові та її компонентів;

- продовжити роботу з розробки нормативно-правових актів з метою імплементації Угоди про асоціацію та адаптація законодавства України до рекомендацій $€ С$ у сфері безпеки крові.

\section{Список використаної літератури}

М03 України (1995) Закон України від 23.06.1995 р. № 239/95 ВР «Про донорство крові та її компонентів» (http://zakon3.rada.gov.ua/laws/show/239/95-вp).

М03 України (2005а) Наказ МО3 України 19.08.2005 р. № 415 «Про удосконалення добровільного консультування і тестування на ВІЛ-інфекцію» (http://www.moz. gov.ua/ua/portal/dn 20050819 415.html).

м03 України (20056) Наказ М03 України від 01.08.2005 р. № 385 «Про інфекційну безпеку донорської крові та її компонентів", «Порядок медичного обстеження донорів крові та (або) її компонентів» (http://moz.gov.ua/ua/portal/dn_20050801_385. html).

М03 України (2010) Наказ М03 України 09.03.2010 р. № 211 «Про затвердження Порядку контролю за дотриманням показників безпеки та якості донорської крові та її компонентів» (http://zakon2.rada.gov.ua/laws/show/z0368-10).

М03 України (2013а) Наказ МОЗ України від 17.12.2013 р. № 1093 «Про затвердження інструкцій 3 виготовлення, використання та забезпечення якості компонентів крові» (http://www.moz.gov.ua/ua/portal/dn_20131217_1093.html).

М03 України (2013б) Наказ МО3 України від 19.02.2013 р. № 134 «Про затвердження Порядку скринінгу донорської крові таїї компонентів на гемотрансмісивні інфекції» (http://www.moz.gov.ua/ua/portal/dn_20130219_0134.html).

Перехрестенко П.М., Горяінова Н.В., Ярошевський В.С. та ін. (2018) Діяльність закладів служби крові України у 2017 році: довідник. ДІА, Київ, 75 с.

Перехрестенко П.М., Тимченко А.С., Малигон О.І. та ін. (2017) Діяльність закладів служби крові України у 2016 році: Довідник. ДІА, Київ, 76 с.

Чугрієв А.М. (2017) Макрооцінка діяльності регіональних служб крові України. Україна. Здоров'я нації, 3: 292-297.

\section{Анализ деятельности учреждений службы крови Украины в 2017 г.}

\section{П.М. Перехрестенко, В.Н. Самусь, Е.М. Аладьева}

Резюме. Анализ деятельности учреждений службы крови - значительное теоретическое и практическое подспорье для планирования работы самой службы, для оценки и планирования ресурсных возможностей направлений медицины, связанных с результатами работы службы какв регионах, таки в целом по Украине. Аналитические материалы предназначены для руководителей управлений здравоохранения, главных областных и городских трансфузиологов, гематологов, хирургов, акушеров-гинекологов, анестезиологов-реаниматологов, специалистов других профилей.

Ключевые слова: доноры, донации, кровь, плазма, эритроцитная масса, тромбоциты, продукция на одного работающего, обеспеченность на 1000 населения.

\section{Analysis of the activities of Ukraine's blood service activities in 2017}

\section{P.M. Perekhrestenko, V.M. Samus, O.M. Aladyeva}

Summary. The analysis of the activities of blood service establishments is a significant theoretical and practical help for planning the work of the service itself, for evaluating and planning the resource opportunities of medical fields related to the service's results both in the regions and in general across Ukraine. Analytical materials are intended for heads of health departments, major regional and city transfusiologists, hematologists, surgeons, obstetrician-gynecologists, anesthesiologists-resuscitators, specialists of other specialties.

Key words: donors, donations, blood, plasma, erythrocyte mass, platelets, products per worker, provision per 1000 population.

\section{Адреса для листування:}

Перехрестенко Петро Михайлович

04060, Київ, вул. Максима Берлинського, 12

Державна установа «нститут гематології

та трансфузіології НАМН України»

E-mail: igt.org@ukr.net 